\title{
THE CASTNER GLACIER REGION, ALASKA
}

\author{
By LAWRENCE E. NIELSEN * \\ (Monsanto Chemical Co., Springfield, Mass.) \\ and
}

Austin S. Post

(Seattle, Wash.)

\begin{abstract}
Three valley glaciers of the eastern Alaska Range are described. On one of these, the Castner Glacier, an unusual medial moraine was discovered, which has its beginning from an outcrop in the center of a cirque-like basin. This large moraine extends down the glacier for 4 miles $(6.4 \mathrm{~km}$.) and ends abruptly several miles from the end of the glacier. The advances and recessional behavior as deduced from end moraines, lateral moraines and the limits of forest destruction (forest trimlines) are briefly discussed.

ZuSAMmBNFASSUNg. Es werden drei Tal-Gletscher der östlichen Gebirgskette in Alaska beschrieben. Auf einem dieser Gletscher, dem Castner Glacier, wurde eine ungewöhnliche Mittel-Moräne entdeckt, deren Ursprung vom Anstehen im Zentrum eines Kar-ähnlichen Beckens herrührt. Diese grosse Moräne erstreckt sich für ungefähr $6.4 \mathrm{~km}$. dem Gletscher entlang und hört plötzlich einige Kilometer vor dem Ende des Gletschers auf. Vorstösse und Rückzüge, die von Endmoränen, Seitenmoränen und den Grenzen von Waldzerstörungen abgeleitet werden, werden kurz besprochen.
\end{abstract}

\section{INTRODUCTION}

Three glaciers flowing in a general westerly direction from the rugged mountains to the east of the eastern Alaska Range terminate at the point where the range is split by the valley of the Delta River. These glaciers - the Castner, the Eel and the Canwell-are readily accessible from the Richardson Highway, which connects Fairbanks in the north with Valdez in the south and runs parallel with the Delta River through the range (see Map, p. 279).

This area is of special interest for several reasons : practically no studies have been made of the valley glaciers of the interior of Alaska, most of the investigations being confined to the coastal region. Several of the glaciers of this area have undergone spectacular advances such as the 3-mile advance of the Black Rapids Glacier during the winter of $1936-37.1,2$ From the description of Mendenhall ${ }^{3}$ it is possible to determine quite accurately the position of the ends of the Castner and Canwell Glaciers as they stood in 1898 . Finally, some of the glacial phenomena observed on the Castner Glacier are extremely unusual.

\section{General Description}

The Castner, a "dendritic" glacier, is a mile ( $\mathrm{r} \cdot 6 \mathrm{~km}$.) wide and has a maximum length of about $\mathrm{I}_{3}$ miles $\left(2 \mathrm{I} \mathrm{km}\right.$.); it covers approximately 32 square miles $\left(8_{3} \mathrm{sq} . \mathrm{km}\right.$.) if tributaries and several small glaciers no longer connected to the main glacier are included. Seven miles (I I km.) from the terminus three main branches of comparable size converge, joining at right angles so as to give the appearance of a cross. The first 4 miles $(6 \cdot 4 \mathrm{~km}$.) of the glacier are covered with heavy ablation moraine, except for the walls of a canyon cut by a superglacial stream. The end is at an elevation of $2500 \mathrm{ft}$. ( $770 \mathrm{~m}$.). Brush, consisting mostly of dwarfed willows but with a few spruce trees, finds nourishment on the more consolidated portion of this ablation moraine below the timber line within a mile or so of the terminus. The remainder of the glacier up to the névé line consists of lanes of clear ice between the large rock-covered medial and lateral moraines. No crevasses are found in the trunk portion of the glacier but are quite numerous in all the branches. The junction of the main branches is at an elevation of $4500 \mathrm{ft}$. ( $1370 \mathrm{~m}$.), the summer snow line, dependent upon the exposure, is between 5000 and $6000 \mathrm{ft}$. ( $1500-1800 \mathrm{~m}$.), while the rugged peaks surrounding the glacier range up to nearly $10,000 \mathrm{ft}$. (3050 m.).

The Eel Glacier, $\frac{1}{2}$ mile $(0.8 \mathrm{~km}$.) wide, occupies a narrow valley just to the south of the Castner Glacier and is ro miles (16 km.) long. It has few branches or prominent side glaciers

* Dr. Nielsen at present holds a Post-doctorate Research Fellowship at Harvard University. 
throughout the length of its sinuous course. However, it receives considerable quantities of ice and rock from great hanging glaciers of a miniature ice cap on the mountain ridge to its south. Ablation moraine covers the ice for the first mile $(\mathrm{r} \cdot 6 \mathrm{~km}$.) and the south margin of the first 5 miles $(8 \mathrm{~km}$.) of the glacier.

The Canwell Glacier is south of the Eel Glacier. It occupies a portion of a long structural valley extending for at least 40 miles $\left(64 \mathrm{~km}\right.$.) in an east-south-easterly direction. Nearly $\mathrm{I} \frac{1}{2}$ miles wide $(2.4 \mathrm{~km}$.), this glacier is rendered conspicuous by its straight even course, sloping gently from névés confluent with the Gakona Glacier at an elevation of about $6000 \mathrm{ft}$. $(1830 \mathrm{~m}$.) to the terminus at $2600 \mathrm{ft}$. $(790 \mathrm{~m}$.) in a distance of about 12 miles $(19 \mathrm{~km}$.). Steep névés cascade from the bordering ridges to join with the trunk ice stream in the highest portion, and a few short tributaries emerge from deep cirques along the southern side. At least one medial moraine indicates by its irregular course a fluctuating or erratic discharge of ice from a lateral tributary.

This portion of the Alaska Range consists mostly of very highly metamorphosed quartzitic rocks-gneisses and mica schists. ${ }^{2}$ These are either banded or intricately folded and contain many quartz veins. Igneous intrusives are very minor.

\section{A Medial Moraine of the Castner Glacier}

An extremely unusual medial moraine was discovered on the Castner Glacier in 1950. This moraine begins at a rock outcrop in the center of the cirque-like basin of the Warrior (north-west) branch of the Castner at an elevation of $5500 \mathrm{ft}$. ( $1680 \mathrm{~m}$.). The moraine extends down the glacier for some $3 \frac{1}{2}$ miles $(5.6 \mathrm{~km}$.) and then abruptly ends at an elevation of $4000 \mathrm{ft}$. ( $1220 \mathrm{~m}$.). (See Map, and Figs. I, 2, 3 and 4, p. 276.) This is the largest and most conspicuous moraine on this portion of the glacier, its surface rising $100 \mathrm{ft} .(30 \mathrm{~m}$.) above the clear ice on either side in one section. Individual rocks up to $50 \mathrm{ft}$. ( $15 \mathrm{~m}$.) in length cover its surface as shown in Figs. I and 3 . It is evident that the large size of the rocks making up this moraine has aided in protecting the underlying ice much more effectively than where the moraines are made up of smaller fragments. This can account at least in part for its superior size and height.

There are several unusual and puzzling features about this moraine. First, the moraine, which is increasing in size and height as it extends down the glacier, ends with surprising abruptness on clear ice. (See Fig. 4.) Secondly, it is unusual to find a large rock outcrop in a cirque basin where the erosional processes are so active. (Fig. 2.)

Since time was not available to make a thorough investigation of this moraine, any hypotheses on its origin must be considered to be purely speculative in nature. However, on the basis of the rock formations, we postulate that the moraine may have been formed in somewhat the following manner : its source, now reduced to a small knob of rock barely exposed, was formerly a ridge or peak extending above the surface of the glacier which active glacial sapping from all sides and frost action above had reduced to a narrow insubstantial spire or spine. The sudden collapse of such a mass would seem a reasonable cause of the abrupt formation of a very large medial moraine and also account for the large size of the fragments of which it is composed. However, in view of the complex formation of these mountains various other suggestions might also be offered. For instance, a small anticline of easily eroded rock capped by a much more resistant rock might have existed in the area now occupied by the cirque. The glacial erosion gradually removed the softer rock from around the hard-capped anticline, thus forming a prominent projection in the cirque floor. Eventually the hard rock covering on the projection was broken and eroded away. Once this had happened, the rock outcrop or projection was exposed to very rapid erosion, and the medial moraine had its birth. Further research will be required to decide which, if either, of these hypotheses is tenable.

\section{RECESSIONAL BEHAVIOR}

All signs indicate a rapid retreat and thinning of the glaciers of this region during the past 50 years. Clear evidence of this is the 2 -mile $(3 \cdot 2 \mathrm{~km}$.) retreat of the Canwell Glacier, the retirement 

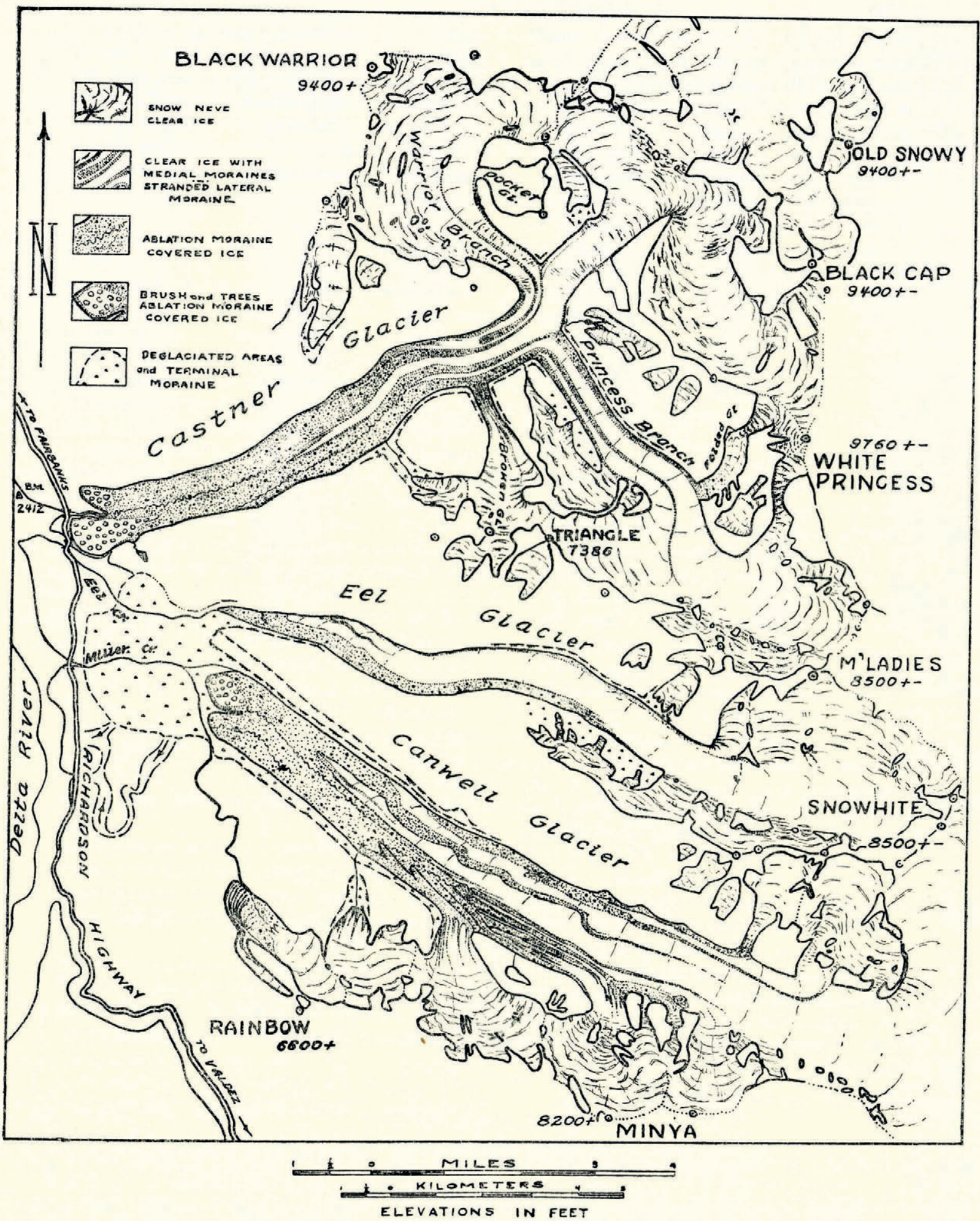
of the Eel Glacier into the narrow canyon in which it now terminates, and the conspicuous barren zones below the most recent lateral moraines, which in many cases indicate a vertical thinning of the glaciers amounting to roo ft. $(3 \circ \mathrm{m}$.) or more. In addition, the present snow line is higher than formerly, as is indicated by the many reduced or even disconnected lateral branches and névé cascades which have until recently augmented the valley glaciers. A few examples of these are the Pocket, Broken, and Slide Glaciers in the Castner basin as well as the striking Folded Glacier, which is now nearly disconnected. This glacier now presents a wall of grimy discolored ice rising $100 \mathrm{ft}$. above the present level of the main glacier and exposes many weirdly contorted bands in the ice from which it derived its name.

Brief examination and investigation of the limits of forest destruction (forest trimlines) suggest that the Castner, Eel and Canwell Glaciers may all at one time have briefly merged into a single glacier in the Delta River Valley. A more recent and prolonged terminus is indicated by the clearly defined terminal moraine of the Canwell Glacier, which closely approaches the Richardson Highway in the vicinity of the Miller Creek Bridge, and which farther north crosses an island separating the present and an abandoned course of Eel Creek. During this stage (shown as a broken line on the map) the Castner and Canwell did not unite, although the Eel was united with the latter. The ice must have been very close to this position when these glaciers were observed in 1898 by Mendenhall, ${ }^{3}$ who noted that brush and trees grew on the ablation moraine-covered surface of both the Castner and Canwell Glaciers, indicating that these ice fronts had been maintained for a considerable period. Mendenhall's description would indicate that the Castner had nearly the same position as to-day. This relatively small recession may be largely explained by the superior thickness of the ablation moraine covering its surface and to its less exposed position.

Drainage from the former expanded Canwell Glacier was quite different from that of to-day, as is clearly shown by the many abandoned stream channels. On the south side of the former glacier there exists a peculiar narrow gorge, now dry, which may be attributed to Pleistocene glaciation of the Delta River Valley. The mouth of this canyon was blocked by the expanded Canwell Glacier, and water issuing from the ice found its way by this circuitous route to the Delta River. The larger portion of the Canwell drainage, however, debouched on the north side of the glacier in the present position of Eel Creek. This stream, augmented by a large portion of the Castner Glacier's drainage escaping on the south margin of that glacier, presented a serious obstacle to travel in $1898 .^{3}$ Retreat of the Canwell and the development of a fixed drainage system for the Castner have changed this; water from the Canwell now reaches the Delta River by a stream known as Miller Creek, and the Castner water is now almost entirely confined to a single channel emerging from a deep notch it has melted into the center of the terminal lobe $\frac{1}{2}$ mile $(0.8 \mathrm{~km}$.) east of the Castner Creek Bridge.

In I950 all three of these glaciers were being depleted at a rapid rate. Although the end of the Castner is retreating more slowly than the Eel and the Canwell, its thickness is decreasing nearly as rapidly as that of the other glaciers. Like the Canwell, its lower portion in the zone of heavy ablation moraine is covered with sink holes and other features indicative of prolonged stagnation such as the depletion and disintegration of side glaciers and névés already mentioned.

The position of these glaciers, all within a few minutes' walk from one of the finest highways in central Alaska, is unique. This opportunity for close examination of large interior glaciers without the organization, expense and discomforts met with in reaching less accessible areas cannot be over-emphasized. It is hoped that more detailed studies will soon be made by others in this interesting region.

M.S. received 14 March 1953

\section{RE F E R E N C E S}

I. Hance, J. H. The recent advance of Black Rapids Glacier. Fournal of Geology, Vol. 45, 1937, p. 775-83.

2. Moffit, F. H. Geology of the Gerstle River district, Alaska, with a Report on the Black Rapids Glacier. U.S. Geological Survey Bulletin 926-B, 1942.

3. Mendenhall, W. C. A reconnaissance from Resurrection Bay to the Tanana River, Alaska, in 1898 . U.S. Geological Survey, 20 th Annual Report-1898-99, Part VII, p. 328. 

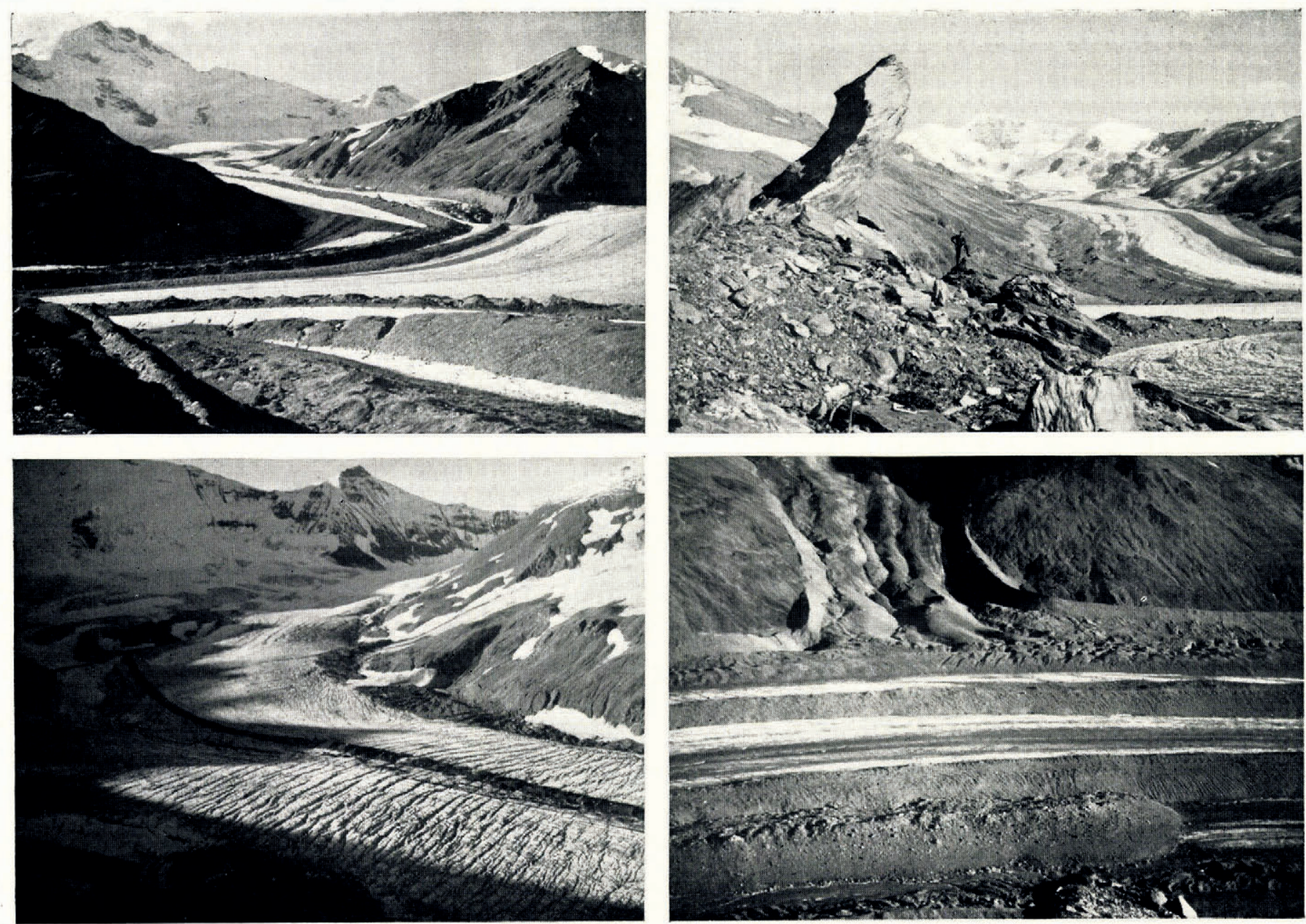

Fig. I (top left). View north-west across the point where the three main branches of the Castner Glacier join. The moraine described in the text originates at the base of Warrior Mt. (left background) and makes a large arc where it joins the other ice streams

Fig.

Fig. 3 (top right). Boulders on the medial moraine near the junction with the other branches of the Castner Glacier. Note the size of the man for comparison. The Princess Branch of the glacier is in the background

Fig

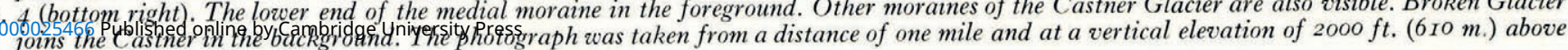
the end of the moraine 